\title{
Free Trade: The Debate on Parallel Importing of Compact Discs
}

\section{Alan Moran}

he two principles that have driven economic success are vigorous competition for the consumer's dollar and firm property rights. 1 Competition drives down prices and forces suppliers constantly to search for cheaper and new ways of meeting consumer needs. Assured property rights ensure the sellers obtain and get to keep the benefits of meeting these needs and give suppliers the confidence to invest in exploring new needs. They allow suppliers to make efficient trade-offs between immediately consuming the income earned from selling their goods and services and ploughing that income back into investment expenditures or lending that will further augment it.

On occasion, the two principles are in collision - preservation of property rights may mean that there is little competition. Property rights include patents and copyright. In one respect such rights entail a monopoly. The artist or inventor is given an entitlement to the rewards others obtain from use of the patent or copyright. The owner of the rights will be expected to milk them for all they are worth, the constraint on this being the willingness of consumers to forego purchases and the ability of the producer to exploit the different buyers' strengths of demand (the different parts of the demand curve). The ability to price differentially is restrained by the ability of buyers to arbitrage between different prices, an ability that is massively increased by the Internet.

Although the issue of $C D$ parallel importing is frequently obscured by allegations of multi-nationals ripping off the consumer and artists, it is patently false to see the music industry as an oligopoly, even if that term were to be analytically useful. There are half a dozen major and hundreds of minor suppliers of CDs. The issue regarding compact discs is fundamentally about the conflict between property rights and competition. It is about whether a producer may be allowed to place a caveat on the sale of her material to control its resale - a denial of which forms an important part of the Trade Practices Act.

Compact discs can now be legally imported into Australia from any country irrespective of the wishes of those that hold copyright over them.

In the debate on this matter, the weight of the economics profession stood almost four square in favour of allowing parallel imports, that were previously banned. The ACCC pressed with considerable vigour to have the ban removed as did many prominent economics columnists like Alan Wood in The Australian. Many academics cut their teeth on the issue as students coveting the lower price 
of textbooks that the dust jackets showed their (usually British) counterparts paid. This price differentiation was due to British booksellers facing a more intensive competitive environment in the UK and/or a more elastic demand in that country.

By contrast to the views of economic commentators, the industry itself, including record artists, were united in favour of retaining a ban. Both sides of the debate represented an economic interest. For all their shouldering of burdens for aboriginal rights, species survival and global temperature levels, artists led in the CD case by Peter Garrett, are in business to make money. And even though there are often bitter disputes between them and their managers and record companies, the latter are the artists' agents.

\section{Effects of Allowing Parallel Importing}

Allowing recorded copyright controlled material to be freely imported into Australia from any other country where it is legally sold, will doubtless place downward pressure on prices. The fact is that in the absence of parallel importing, some material is likely to be priced higher in some markets than in others. Freedom of trade will tend to equalise all prices, normally by bringing them down to those in the lowest priced market. An article in The Australian Financial Review (Kath Cummins, 'Sanity Records may prevail in slowdown over CD retail prices', 7 January 1999) estimated the wholesale costs of imported CDs to be 50-55 per cent of the cost of Australian-supplied disks.

The lower prices are unlikely to be in the best interests of the copyright owners - if they can charge differential prices, they will obtain higher profits. Although superficially attractive for consumers (once the market forces have pressured the initial importer to lower prices in line with costs) this may not be the best outcome for consumers. Low prices are only one component of consumer demands and if they come at the expense of a constrained variety of offerings they may not be the preferred outcome. One single car plant that fully exploited all economies of scale in turning out just one model would not necessarily be beneficial to consumers.

Any firm will seek to segment the market where it can and exploit the demand spectrum by charging a higher price to those with the greatest wish for their product and capability of paying for it.

We see this in a great many markets. There need be no market power, as conventionally understood, to allow the exercise of price discrimination. The 'law of one price' normally prevails in open markets but suppliers faced by different demand curves for different market segments will often charge different prices. Exploiting different demand profiles is known as Ramsey pricing and a long and uncontroversial literature suggests that it promotes efficiency. The difficulty is defining the segments so that the discrimination can take place. 
In charging lower prices in some markets, the seller will be keen to prevent higher charged customers migrating to these to take advantage of them. This puts constraints on the ability to structure separate prices. Yet we do find this taking place. Thus, cinemas and hairdressers charge different prices for pensioners and children (in the case of hairdressers, children are also more difficult to serve!). By no stretch could the market for these services be said to lack competition, although the Victorian Government is striving manfully to restrain new cinema competition. Nor should the authorities see a role for themselves to step in and enforce a single price.

\section{Implications of Removing the Ban on Parallel Imports}

Almost all products have an element of monopoly which is promoted by branding and differentiation from competitive products. The objective is to earn greater profit. There are practical constraints on the ability to price differentiate across markets as a result of Internet ordering. But why should an artist or inventor not try to obtain the best return for his or her product? Although short term price reductions may follow from regulatory action forbidding price differentiation, over the longer term it will reduce returns to innovation and the amount of innovatory activity. To put in place restrictions, we must therefore be taking the view that there is too much innovation. This amounts to a new paradigm, which its proponents must justify.

Although the prevention of parallel imports could be seen as an infringement on free trade, it can also be seen as the protection of the property rights of those holding copyright. Broadly speaking, any diminution of the property rights people hold will mean reduced incentives to develop the property rights in the first place.

Increased revenues consequent on the ability to differentiate prices accrue to either record companies or artists. Individual record companies will receive increased revenue if they have some unique skills in setting optimum prices for each market. Maintaining such unique skills, however, is most unlikely and once rivals have the same skills, the benefits are passed either to:

- artists with established reputations; these benefits may come in greater remuneration or additional promotional expenditures; or

- artists with no reputation, who will see a greater likelihood of being offered contracts; the potential returns from the cultivation of unknowns is made slightly greater by the abilities of the record companies to earn more revenue by price discrimination and more such risk taking by the $\mathrm{CD}$ producers will therefore take place. 
In the absence of a cartelised industry, competition will mean the record companies do not earn super profits for their shareholders. No matter in which of the other two directions the increased revenues can go in the longer term, they would be efficiency enhancing.

In fact, because the CD supply market is intensely competitive, any 'rents' from price discrimination are likely to fall to the suppliers of the scarce goods: namely the artists. The artist has a unique product and is faced by many possible processors and marketers of that talent. Why should he or she be prevented from seeking the best return for these creative efforts?

In addition to reducing income for successful artists, constraining the conditions of supply to prevent price discrimination reduces opportunities for new artists. A CD producer has a great many options in promoting new acts and would lose money in nineteen out of twenty such innovations. If producers are impeded from seeking to maximise revenue from their products, they must be more cautious in offering opportunities for new performers. Accordingly, price reductions from intervening in market processes may bring a short term gain to consumers but will mean a future loss in diversity of output.

In many markets the ability to segment offers opportunities that would otherwise be denied. In a recent case involving jeans, the European Court allowed the denial of parallel imports to continue. Levi's made in Bulgaria for the East European market were being exported into EU countries and undercutting the regular Levi supplied product. The Court allowed Levi Jeans to prevent this resale of its Bulgarian jeans.

Levi were able to provide the product to Bulgaria at a marginal cost. Had the firm been obliged to sell the product at that same low price worldwide, it would surely have opted to cease supply from the Bulgarian factory, to the disadvantage of Bulgarian consumers as well as itself.

The following table offers a simplified example. Levi is a firm that has established a strong reputation for quality products and an ex-factory sale price of $\$ 10$ per pair makes a gross margin of $\$ 8$. Selling 5 million pairs in Western Europe, it grosses $\$ 40 \mathrm{~m}$ profit. Its customers see other options but gain on average a welfare surplus of $\$ 3$ per pair. In Eastern Europe, sales would be very much lower at the Western European prices, but if the firm is able to insulate the two markets, it can still make profitable sales charging only $\$ 3$ per pair. In doing so, its overall gross profits are $\$ 42 \mathrm{~m}$. East European consumers make a welfare gain of $\$ 2$ per pair and consumers overall make a gain of $\$ 19 \mathrm{~m}$.

If forced to allow parallel importing Levi would close down its East European facilities or otherwise act to preserve its gross margins in the more important West European market. It would make modest sales at the West European prices in Eastern Europe and see its profits fall to $\$ 40.8 \mathrm{~m}$. The aggregate consumer welfare gain would also fall from the $\$ 19 \mathrm{~m}$ without parallel importing to $\$ 15.2 \mathrm{~m}$. 


\begin{tabular}{|c|c|c|c|c|}
\hline \multirow[b]{3}{*}{$\begin{array}{l}\text { Producer gross gain } \\
\text { price }(\$)\end{array}$} & \multicolumn{2}{|c|}{$\begin{array}{l}\text { Position with no Parallel } \\
\text { Imports }\end{array}$} & \multicolumn{2}{|c|}{$\begin{array}{l}\text { Position with } \\
\text { Parallel Imports }\end{array}$} \\
\hline & W. Europe & E. Europe & W. Europe & E.Europe \\
\hline & 10 & 3 & 10 & 10 \\
\hline Sales & $5,000,000$ & $2,000,000$ & $5,000,000$ & 100,000 \\
\hline Profit per unit (\$) & 8 & 1 & 8 & 8 \\
\hline Profit to Levi (\$m) & 40 & 2 & 40 & 0.8 \\
\hline $\begin{array}{l}\text { Consumer welfare } \\
\text { gain }\end{array}$ & & & & \\
\hline per unit (\$) & 3 & 2 & 3 & 2 \\
\hline $\begin{array}{l}\text { Total consumer } \\
\text { welfare gain }(\$ \mathrm{~m})\end{array}$ & 15 & 4 & 15 & 0.2 \\
\hline
\end{tabular}

Of course, it might be argued that the consumer would be better off if all sales were to be made at the East European price of \$3, but forcing such an outcome would deliver a forceful message to all firms contemplating the profitable supply of markets with lower purchasing power capacities.

Thus the CD debate cannot be couched simply in terms of requiring freedom of trade. It is also a conflict between the freedom of individuals to pursue their own interests versus one that would constrain that freedom in favour of competition. The issue is, should an artist (through his agent the record producer) be allowed to retain control of his material after its first sale? It is, after all her property and almost anything a regulator does to dictate its use will detract from its value to her. 